\title{
Expressões contemporâneas do imperialismo e desafios à sua análise
}

\author{
Sheyla Suely de Souza Silva ${ }^{1}$ \\ https://orcid.org/0000-0003-1469-6419 \\ ${ }^{1}$ Universidade Estadual da Paraíba, Departamento de Serviço Social, Campina Grande, PB, Brasil \\ ${ }^{1}$ Universidade Nova de Lisboa, Instituto de História Contemporânea, Grupo de História do Trabalho Global e dos \\ Conflitos Sociais, Lisboa, Portugal
}

\section{Expressões contemporâneas do imperialismo e desafios à sua análise}

Resumo: Este artigo aborda o fenômeno do Imperialismo, suas determinações e expressões. A partir da pesquisa bibliográfica e do recurso às categorias do método histórico-dialético, o estudo tem por objetivo apresentar uma síntese, histórico-críticodialética, dos fundamentos da emergência do Imperialismo, suas transformações no período pós-guerras e, principalmente, suas determinações e expressões mais contemporâneas. Seus resultados indicam que a crise de 2008 impôs novas implicações à ofensiva imperialista, donde se destaca a transição para uma fase ultraneoliberal, que, além de acirrar as pautas da ortodoxia neoliberal dos anos 1980, agrega novos elementos, tais como o autoritarismo e conservadorismo políticos e a consequente redução das dinâmicas democráticas; o acirramento das espoliações e a vigilância, controle e manipulação digital das populações.

Palavras-chave: Imperialismo. Novo Imperialismo. Ultraneoliberalismo. Espoliações. Expropriações.

\section{Contemporary expressions of imperialism and challenges to its analysis}

Abstract: This article addresses the phenomenon of Imperialism, its determinations and expressions. Based on bibliographic research and use of the categories of the historical-dialectical method, the study aims to present a synthesis, historicalcritical-dialectic, of the fundamentals of the emergence of imperialism, its post-war transformations and, mainly, of its determinations and expressions more contemporary. The results indicate that the 2008 crisis imposed new implications on the imperialist offensive, from where stands out the transition to an ultraneoliberal phase that, in addition to intensifying the guidelines of the neoliberal orthodoxy of the 1980s, adds new elements, such as authoritarianism and political conservatism and the consequent reduction in democratic dynamics; the intensification of spoliations and surveillance, control and digital manipulation of populations.

Keywords: Imperialism. New Imperialism. Ultraneoliberalism. Spoliations. Expropriations.

Recebido em 09.11.2020. Aprovado em 15.12.2020. Revisado em 25.02.2021.

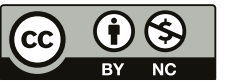

Este é um artigo publicado em acesso aberto (Open Access) sob a licença Creative Commons Attribution NonCommercial, que permite uso, distribuição e reprodução em qualquer meio, sem restrições desde que sem fins comerciais e que o trabalho original seja corretamente citado. 


\section{Introdução}

As recentes transformações no cenário político brasileiro, desde o golpe de 2016, o qual implicou na derrubada do Governo Dilma Rousseff, vêm imprimindo severas modificações nas políticas que integram a Seguridade Social brasileira, sendo esta última, ao longo dos últimos vinte e três anos, objeto central de nossos estudos acadêmicos. Tendo como aporte o recurso heurístico à categoria da totalidade, julgamos imprescindível analisar as determinações universais do capital sobre todo este processo, o que necessariamente nos conduziu ao objetivo de compreender o fenômeno do Imperialismo, desde a sua emergência, até, principalmente, suas expressões e ofensivas mais recentes.

É nessa perspectiva que, por meio deste texto, sintetizamos e socializamos alguns resultados de nossa pesquisa bibliográfica acerca do Imperialismo, desde sua emergência, no início do século passado, até suas mais recentes transformações, suscitadas pela crise de 2008 e seus desdobramentos, donde se destacam o acirramento do endividamento mundial, público e privado; as alterações nas disputas interimperialistas e a transição para o ultraneoliberalismo, através do qual exacerbam-se as espoliações e expropriações.

As próximas seções do artigo apresentam, respectivamente, os fundamentos da emergência do Imperialismo; as suas transformações no contexto do pós-guerras; a mundialização financeirizada, flexível e neoliberal do capital e, neste processo, o acirramento das espoliações e expropriações empreendidas pela Oligarquia Financeira internacional, com o apoio dos Estados nacionais, através da reestruturação produtiva e do neoliberalismo; a crise de 2008, suas contradições e desdobramentos, em que se destaca o ultraneoliberalismo; e, finalmente, nas considerações gerais, sintetizamos os principais traços contemporâneos do Imperialismo e do ultraneoliberalismo.

\section{Breves notas sobre a emergência do Imperialismo}

No início do século XX, Lênin (2012) evidenciou a emergência da fase imperialista do capital ${ }^{1}$, destacando que a concentração bancária constituiu o processo fundamental da transformação do capitalismo monopolista em Imperialismo. O crédito passou a subsidiar diretamente o processo produtivo ${ }^{2}$, a depender desse processo produtivo para obter sua própria remuneração e a gerir o processo produtivo, impulsionando a extração de mais valor e a concentração do capital monetário (FONTES, 2010).

Dispondo desse capital monetário, concentrado e sobreacumulado, e empreendendo um processo que Lênin (2012) nominou de partilha do mundo, Inglaterra, França, Estados Unidos e Alemanha se configuraram como os primeiros países banqueiros, exportadores para e credores de quase todo o resto das nações, transformando-as em economias devedoras e dependentes. O Imperialismo e a dependência passaram a ser estruturais no sistema do capital e a dívida pública um determinante central, implicando na subordinação das economias periféricas. Durante os anos 1970, dedicando-se aos estudos sobre a dependência, Ianni (1974, p. 175) avaliou que Imperialismo e dependência conformam uma unidade dialética, pois, "[...] um e outro se constituem reciprocamente, como expressões necessárias da reprodução ampliada do capital, em escala mundial" ${ }^{3}$ Fontes (2010, p. 119) avalia que a subordinação dos países dependentes aos imperialistas passaria:

[...] a se assemelhar [...] ao domínio do capital sobre o trabalho: ela se apresenta como adesão voluntária, como resultante da própria necessidade dos países de se 'desenvolverem', de se 'modernizarem', para os secundários, ou para manterem suas posições capital-imperialistas. A violência constitutiva dessa dinâmica multiplamente subordinadora se faz envolta em ameaças difusas, brandidas explicitamente pelos apologistas da 'globalização': ou se incorporam ou perecerão, banidos do comércio e dos créditos internacionais.

Em brevíssima síntese, ancorados nesses autores, destacamos que a concentração de capitais e o monopólio, o sistema colonial, a exportação de capitais e a dívida pública constituíram-se nos principais fundamentos clássicos da emergência do Imperialismo ${ }^{4}$ e conduziram os países imperialistas a um movimento de partilha do mundo, o qual culminou em duas grandes guerras mundiais. Segundo diversos estudiosos do Imperialismo, no período pós-Segunda Guerra, esse fenômeno apresentou novas determinações, expressões e tendências ${ }^{5}$, as quais abordaremos a partir do item a seguir. 


\section{Determinações e expressões do Imperialismo no período pós-guerras}

Para Harvey (2014), a partir do pós-guerras deu-se uma transição do imperialismo leve, calcado no colonialismo e na exportação de capitais, para um novo imperialismo, calcado na plena espoliação das economias dependentes. Assim, diante de dificuldades na sua histórica acumulação expandida, durante a extensa crise estrutural que o assola, o Novo Imperialismo empreende a acumulação por espoliaçã o $\sigma^{6}$, priorizando ofensivas fraudulentas e predatórias, com vistas à apropriação de riquezas naturais e sociais, a nível planetário e, para tanto, os Estados nacionais foram convocados a promover práticas espoliativas (HARVEY, 2014, p. 122)7. Essa assertiva corrobora as observações de Mészáros (2011) quanto a uma potencialização da intervenção estatal, devido ao sistema do capital já não conseguir solucionar suas contradições mais explosivas na dimensão da relação econômica. Também para Chesnais (2005), a mundialização financeira vem demandando aos Estados nacionais o tripé da liberalização, desregulamentação e privatização.

Fontes (2010) evidencia que o atual capital-imperialismo emergiu sob a institucionalidade das entidades internacionais criadas no pós-guerras ${ }^{8}$, visando "assegurar a coordenação econômica e mercantil de empreendimentos com enorme abrangência e que exigiam grande mobilidade espacial, elaborando formas de 'automatização' local da gestão sem redução da unidade de ação no plano internacional" (FONTES, 2013, p. 09) ${ }^{9}$ e, neste contexto, a exacerbação da concentração do capital em sua forma monetária colocou-nos diante "[...] da mais extrema potencialização da propriedade capitalista tout court, que se torna abstrata, desigualitariamente socializada e extremamente destrutiva" (FONTES, 2010, p. 85).

Assim, se durante a acumulação primitiva o capital procedeu à transformação da propriedade privada comunal em uma propriedade privada individual e baseada no critério da exploração do trabalho alheio ${ }^{10}$, o capital-imperialismo procedeu a uma nova transformação da propriedade do capital, elevando-a a uma dimensão de propriedade altamente concentrada e desvinculada das empresas particulares e dos meios de produção propriamente ditos.

Ao mesmo tempo em que essa nova propriedade monetária concentrada “[...] supera as dimensões da empresa e de qualquer empreendimento singular, configurando-se como o fetiche máximo de uma potência cega de pura forma monetária" (Fontes, 2010, p. 85), também permite ao capital-imperialismo "[...] garantir a centralidade máxima de valorização do valor - sobre qualquer outra instância, inclusive a empresa" (FONTES, 2010, p. 115), em escala planetária. Ou seja, mesmo desvinculada da materialidade física das unidades empresariais, a nova propriedade monetária concentrada não prescinde da existência das mesmas, antes, lhes impõe uma extração de mais-valor capaz de subsidiar a reprodução do capital funcionante (reinversão) e remunerar com juros o capital monetário ${ }^{11}$. O resultado desta ingerência orgânica do capital financeiro sobre os capitais funcionantes em geral é a exasperação das expropriações (FONTES, 2010, p. 21-24) ${ }^{12}$.

A nosso ver, as espoliações e expropriações discutidas por Harvey (2014) e Fontes (2010) e apresentadas nesse item tratam-se de despossessões que guardam similaridades e peculiaridades; vejamos.

\section{A mundialização financeirizada, flexível e neoliberal: proletarização, precarização e apropriação de riquezas, em escala planetária}

Fontes (2010) ressalta que o capital engendra duas formas de propriedade: a dos meios de produção e a dos recursos sociais de produção e, para acirrá-las, exaspera as expropriações dos trabalhadores, primárias e secundárias e, a nosso ver, exaspera também a espoliação de riquezas, naturais e sociais, num recrudescimento das práticas da chamada acumulação primitiva, conforme propõe Harvey (2014), para deter tanto a capacidade real e atual de produção efetiva (basicamente, os meios de trabalho, força de trabalho, matérias primas, maquinário, infraestrutura etc., postos em ação para a produção), quanto o monopólio de toda a capacidade potencial da produção mundial, incluindo todo o desenvolvimento técnico-científico, a riqueza real e as formas de ativos, ainda que para serem mantidos ociosos.

Para favorecer essa propriedade concentrada, as expropriações alijam o trabalho dos meios de produção e, também, da capacidade social de produção; do controle e gestão da produção; da apropriação dos produtos e de qualquer possibilidade de compreender, criticar e resistir à sua própria expropriação e proletarização ${ }^{13}$. A continuidade das expropriações primárias (despossessão dos meios de produção) e a emergência das 
expropriações secundárias (despossessão dos bens e direitos sociais e trabalhistas conquistados) tornam os trabalhadores disponíveis para qualquer modalidade de trabalho, desde as remanescentes formas mais estáveis até as mais absolutamente precárias.

Observe-se que isto, hoje, se dá no contexto do capitalismo tardio, o qual - marcado por uma sobreacumulação crônica, pela disjunção entre sua original produção genuína e a atual autorreprodução destrutiva e por uma crise estrutural sem precedentes - desfaz, conforme previu Mészáros (2011, p. 673), a "[...] ilusão da 'integração' permanente do trabalho" e legitima "[...] a mais antissocial e desumanizante tendência [...] para a expulsão brutal do trabalho vivo do processo de trabalho".

Para fazer frente ao desemprego estrutural crônico - e na impossibilidade de superar a contradição basilar da lei geral da acumulação capitalista entre a expulsão do trabalho para aumento da produtividade e extração de mais-valor e a consequente redução do consumo - a reestruturação produtiva e o neoliberalismo, ao tempo em que dão sequência à expropriação e proletarização em escala massiva, adaptam os trabalhadores a condições generalizadas de precariedade e subproletarização, como forma de viverem na permanente condição de superpopulação relativa estagnada e crônica $^{14}$.

As despossessões, mais que nunca, empreendem a apropriação predatória de todo e qualquer recurso social de produção, ora em favor da extração imediata de mais-valor, ora para mantê-lo ocioso, em favor do monopólio dos países imperialistas sobre todas as potencialidades de produção a nível planetário. Ou seja, no atual contexto de produção destrutiva, sobreacumulação crônica e desemprego estrutural, expandem-se despossessões que visam à simples apropriação e monopólio das riquezas planetárias, para o controle absoluto do potencial social de produção, e o capital converte-se num "[...] dreno espoliador do sociometabolismo básico do nosso lar planetário" (MÉSZÁROS, 2011, p. 631) ${ }^{15}$.

Os Estados nacionais são, então, convocados a promover espoliações e expropriações, através de uma reestruturação no âmbito da produção - que repercute na divisão internacional do trabalho — e no âmbito da reprodução social, através do já citado tripé de liberalização, desregulamentação e privatização (CHESNAIS, 1996). É nessa perspectiva que, especialmente a partir dos anos 1980, a mundialização do capital é financeirizada, flexível e neoliberal, visando à livre, instantânea e volátil mobilidade do capital, num fluxo internacional, ilimitado e ininterrupto de transações comerciais e financeiras e de espoliações e expropriações ${ }^{16}$.

No âmbito estrito da produção, a reestruturação torna predominantes as modalidades precárias de trabalho e destrói o chão da fábrica como referência da identidade, organização e luta da classe trabalhadora ${ }^{17}$; na esfera da reprodução social, inflexionam-se as instituições políticas, jurídicas, econômicas, culturais e científicas para forjar o Estado, as leis, a escola, a religião, a arte etc., de forma que correspondam ao imperativo de adequar o comportamento dos homens às exigências de produção e acumulação do capital que passaram a viger e, para isto, o neoliberalismo foi retirado das gavetas da história ${ }^{18} \mathrm{e}$ posto em prática pelos Estados nacionais, sob a orquestração das agências internacionais.

Além da imposição de suas pautas macroeconômicas, que operacionalizam o tripé de liberalização, desregulamentação e privatização ${ }^{19}$, o neoliberalismo alcança todas as outras esferas da vida e dissemina pensamentos, teorias, códigos de comportamento e programas de governo que criam um novo sujeito para uma nova razão do mundo, pautada no valor da concorrência absoluta entre os homens, tomados, cada um deles, como uma empresa humana ou unidade do capital. Este processo objetivo e subjetivo de subsunção do trabalho devasta a consciência de classe dos trabalhadores, ao identificá-los com e convencê-los das designações — individualistas, fragmentárias e competitivas — de capital humano, sujeito-empresarial e empreendedor (DARDOT; LAVAL, 2016) ${ }^{20}$.

As contribuições sintetizadas até este momento nos apresentam os fundamentos da emergência do Imperialismo e nos aproximam de suas novas determinações e expressões no contexto do pós-guerra e da crise estrutural que se arrasta desde a década de 1970 - donde se destacam a nova propriedade monetária concentrada do capital, o recrudescimento das espoliações, a Oligarquia Financeira internacional e a mundialização financeirizada, flexível e neoliberal -, mas o quadro histórico desse Novo Imperialismo sofreu severas alterações a partir do crash de $2008^{21}$ e suas inflexões em 2011-2012 e em 2019-2020, agravando-se com a pandemia da COVID-2019, o que nos desafia a novos aprofundamentos. 


\section{Crise e pós-crise de 2008: explicitação e aprofundamento das contradições e das retóricas do neoliberalismo}

Nos primeiros anos do século XXI houve um aumento exponencial da propriedade monetária concentrada do capital. Segundo Duménil e Lévy (2011), até 2008, a renda e riqueza das classes superiores foi quintuplicada. No entanto, tudo isto se realizou à custa da criação de uma estrutura financeira que, desregulamentada, tornou-se desequilibrada e vulnerável a riscos, especialmente nos Estados Unidos (EUA), cuja hegemonia internacional lhes permitiu "[...] seguir uma trajetória macro de aumento dos desequilíbrios doméstico e internacional", e cujo colapso espraiou-se para o resto do mundo (DUMÉNIL; LÉVY, 2011, p. 7).

A globalização do sistema bancário promovida pelo neoliberalismo - expressa em altos volumes de Investimentos Estrangeiros Diretos (IEDs) e de créditos bancários estrangeiros às economias nacionais (dívidas públicas e privadas) ${ }^{22}$ - a um só tempo, favoreceu um processo de aceleração do crescimento econômico, especialmente nos primeiros sete dos anos 2000, e gestou os pontos de estrangulamento que colapsaram em 2008 , tendo como epicentro a economia dos EUA ${ }^{23}$. Neste país, a financeirização estrangeira, especialmente no setor imobiliário, acirrou o endividamento das famílias, o déficit no comércio exterior e a dívida interna, principais elementos que detonaram o crash e converteram a onda de crescimento dos sete anos anteriores em um quadro de recessão, repercutindo nas demais economias nacionais.

Tanto nos Estados Unidos quanto na Europa, o socorro dos tesouros públicos aos agentes privados que especularam irresponsavelmente na ciranda financeira, a qual eles mesmos desregulamentaram, foi bastante expressivo e pôs por terra, irremediavelmente, qualquer retórica que atribua ao neoliberalismo o princípio do chamado Estado mínimo. Segundo Cunha et al. (2015), de imediato, o Federal Reserve (Banco Central americano) destinou US\$ 180 bilhões aos bancos e o Tesouro Nacional americano comprou ativos podres de instituições financeiras privadas, na ordem de US\$850 bilhões. Os bancos centrais da Alemanha, França e Espanha desembolsaram, respectivamente, meio trilhão de dólares, US\$ 350 bilhões e US\$ 100 bilhões em socorro público às agências financeiras privadas.

Após o socorro imediato aos bancos, segundo os mesmos autores (CUNHA et al., 2015), sucederam-se montantes destinados à recuperação da crise, compostos por US $\$ 787$ bilhões para a retomada do crescimento da economia norte-americana e um trilhão de dólares foi desembolsado pelo Fundo Monetário Internacional (FMI) para a recuperação da economia mundial, sendo US $\$ 750$ bilhões destinados diretamente ao sistema financeiro global e US $\$ 250$ bilhões destinados a políticas de impulsão do comércio e de combate ao protecionismo.

Embora a crise de 2008 tenha explicitado as contradições e riscos da ofensiva neoliberal, não a pôs em xeque, pois preservou-se "intacta a estrutura básica da especulação" financeira mundial (CUNHA et al., p. 9), liberalizada e desregulamentada, dando prosseguimento e aprofundamento ao curso da mundialização financeirizada, flexível e neoliberal e fazendo eclodir novas crises, como a de 2011 e a de 2019, tendo a primeira o seu detonador nas dívidas soberanas (DUMÉNIL; LÉVY, 2011; CUNHA et al., 2015;) e esta última na esfera da produção (TOUSSAINT, 2020).

Segundo Duménil e Lévy (2011), o pós-crash de 2008 é marcado, até 2011, por modestas recuperações do PIB norte-americano, taxas negativas de crescimento nas economias da Europa e crescimento ínfimo nos países em desenvolvimento (China, Índia e Brasil, notadamente), quadro que, em última análise, expressa uma baixa recuperação do sistema a nível internacional, a manutenção da instabilidade financeira e do socorro dos governos e bancos centrais, o agravamento das dívidas e uma desindustrialização generalizada.

Apenas a partir de 2011 os países retomam uma trajetória mais estável de baixas taxas de crescimento, mas este parco crescimento se dá, primeiro, sob a manutenção do receituário de desregulamentação, pois as recomendações de disciplinamento não passaram de anúncios retóricos ${ }^{24} \mathrm{e}$, segundo e consequentemente, à custa da explosão das dívidas, privadas e soberanas, uma vez que o crescimento é obtido no âmbito financeiro através do sistema de crédito e do endividamento contínuo. Por outro lado, o sistema não retomou sua autonomia, ficando viciado no socorro público estatal, impondo também aos Estados nacionais uma situação crescente de endividamento. Segundo Botelho (2018), o endividamento total mundial teve um crescimento de 40\%, entre 2007 e 2017, atingindo um montante estimado em 237 trilhões de dólares, o que corresponde a $317 \%$ do PIB mundial.

Toda essa instabilidade se agrava devido à hegemonia da economia e da moeda americana sobre as demais economias mundiais, as quais terminam financiando os déficits orçamentários e comerciais dos Estados 
Unidos, que não conseguem crescer sem endividamento e reagem à ameaça de perda de sua hegemonia imperialista, disputando-a com outras novas potências mundiais, notadamente a China, cuja economia, não tendo aderido integralmente ao receituário neoliberal, disputa a liderança econômica mundial ${ }^{25}$. É nesse contexto de agravamento da instabilidade e de disputa que os Estados Unidos chegam a 2014 com " [...] cerca de 40 trilhões de dólares em obrigações a pagar por parte do governo, empresas e famílias, algo como um quinto de toda a dívida mundial" e cerca de $233 \%$ do seu próprio PIB. A China, embora com endividamento menor, foi responsável por 40\% do endividamento mundial, entre 2007 e 2014 (BOTELHO, 2018, p. 6).

Sob as inflexões do crash de 2008, o endividamento e as disputas entre os países centrais repercutem no endividamento, nas exportações (especialmente de commodities), na estabilidade monetária e na vida política, social e cultural dos países periféricos, cujas dívidas se elevam; as exportações sofrem arrefecimentos, devido à redução de demanda por commodities; e seus Estados são convocados a acirrar processos internos de espoliações e expropriações, que, primeiro, sob a retórica de um necessário ajuste fiscal, exercem uma mão pesada na destruição maciça e célere dos bens e direitos sociais, direcionando os fundos públicos para o sorvedouro das dívidas, e, segundo, com o consentimento ativo de suas burguesias internas, empreendem uma entrega robinhoodiana de recursos naturais e sociais, para o usufruto da lógica espoliativa do sistema, ao preço de verdadeiros crimes de lesa pátria e de lesa humanidade ${ }^{26}$.

Àqueles que, diante da crise de 2008, apostaram otimistas num pós-neoliberalismo ${ }^{27}$, o capital respondeu com um ultraneoliberalismo, conduzindo o sistema ao recrudescimento de suas próprias contradições absolutas, de sua crise estrutural, de suas instabilidades financeiras e, consequentemente (como forma de tentar dar lastro a uma riqueza que está largamente baseada em obrigações de pagamentos futuros e capital fictício), de suas investidas espoliadoras e expropriadoras ${ }^{28}$.

Em objetivada barbárie, ascendem novos processos de conservadorismo e autoritarismo políticos, que mobilizam traços de fascismo; "desdemocratizações" das dinâmicas políticas nacionais; pilhagem de bens e patrimônios nacionais e genocídio de populações nativas; espionagem, vigilância e controle digital das populações etc. Esses eventos são potencializados pela atual agenda ultraneoliberal, visando ao domínio absoluto da Oligarquia Financeira mundial sobre a universalidade do trabalho e da riqueza planetária.

Por outro lado, as inflexões contínuas do crash de 2008 explicitam as contradições absolutas do capital, pois mesmo que as grandes potências econômicas mundiais disputem a hegemonia do Imperialismo, este fenômeno, imanente ao sistema do capital, atinge todas as economias nacionais, repercute, de variadas formas, sobre os trabalhadores de todo o planeta e tensiona a luta de classes. No período pós-crash de 2008 , sob a persistência e aprofundamento da mundialização financeirizada, flexível e, agora, ultraneoliberal, todas as economias nacionais e as grandes empresas encontram-se sobre-endividadas; todas as economias, à exceção da China, enfrentam crise na produção e todas as economias não imperialistas vivenciam um processo de desindustrialização. Enquanto isso, durante os episódios financeiros de 2008, 2011 e o atual, iniciado em 2019-2029, grandes massas de capital viraram fumaça.

Se, por um lado, as severas ofensivas do capital, na sua atual mundialização financeirizada, flexível e ultraneoliberal, ameaçam a vida do planeta, dos trabalhadores e da humanidade como um todo, por outro lado elas explicitam o desespero do sistema para obter sobrevida diante do acirramento de suas próprias contradições absolutas e impostergáveis.

\section{Considerações Finais}

Através do recurso heurístico às categorias da totalidade, historicidade e contradição, sintetizamos os fundamentos da emergência do Imperialismo, suas transformações no período pós-guerras e suas novas determinações, desde o crash de 2008, o qual interpretamos como uma crise conjuntural, dada na esfera financeira e com ampla abrangência sobre as economias nacionais, tanto centrais quanto periféricas, e do qual, dentre outros elementos, destacamos como principais: a) impacta sobre a crise estrutural, que se desenrola desde a década de 1970, agravando suas contradições, nos âmbitos da produção e da reprodução do capital; b) acentua (estratosfericamente) tanto o endividamento mundial, quanto a distância entre o capital fictício e seu (não)lastro real; c) impõe alterações nas disputas interimperialistas pela hegemonia político-econômica sobre o sistema do capital e a totalidade social; d) precipita o neoliberalismo para uma nova fase, ultraneoliberal. 
Esta nova fase ultraneoliberal é empreendida pela Oligarquia Financeira internacional e sua propriedade monetária concentrada, com vistas à obtenção de um domínio absoluto sobre a universalidade do trabalho e a riqueza planetária, e - além de dar severidade e celeridade ao receituário da ortodoxia neoliberal, donde se destacam o acirramento do ajuste fiscal, para a apropriação dos fundos públicos nacionais; as privatizações de empresas estatais e bens comuns (água, terra, saberes nativos, bens e valores culturais etc.) e a destruição dos direitos trabalhistas e sociais conquistados pelos trabalhadores —, agrega novos elementos a serem aprofundados, dentre os quais nos parece válido destacar neste texto, ainda que introdutoriamente: a) a ascensão mundial de um novo processo de conservadorismo e autoritarismo políticos, o qual mobiliza, onde necessário e possível, traços de fascismo, o que implica b) numa desdemocratização das dinâmicas políticas nacionais; c) a expansão das espoliações que visam à pilhagem de bens e patrimônios nacionais, implicando, inclusive, no genocídio de populações nativas, e que também (re)colocam a América Latina na rota central das ofensivas imperialistas dos Estados Unidos; d) a espionagem, vigilância, controle e manipulação digital das populações.

É preciso lembrar que essas ofensivas não se dão sem a resistência do trabalho. Encontramo-nos, como nunca, no olho de um furacão chamado Luta de Classes; prova disso são as convulsões sociais em todo o mundo, tais como o movimento dos Coletes Amarelos, na França (2018); as greves de trabalhadores do Google (2018), trabalhadores do Uber (2019) e trabalhadores de entrega por aplicativos (2020), respectivamente, nos Estados Unidos, Europa e Brasil, consideradas as novas greves dos trabalhadores do futuro; a mais recente eleição da esquerda na Bolívia e as recentes derrotas do neoliberalismo no Chile, ainda que após trinta anos de expropriações.

Enfim, entendemos que, primeiro, esta análise das determinações e expressões mais contemporâneas do Imperialismo, dadas na universalidade da relação social capitalista, foi realizada como pressuposto heurístico imprescindível à compreensão das ofensivas à Seguridade Social, dadas na particularidade brasileira e, segundo, que o real é forjado por contradições e é nelas que estão as potencialidades das nossas lutas; mas, antes, é preciso compreendê-las.

\section{Referências}

ABÍLIO, L. C. O make up do trabalho: uma empresa e um milhão de revendedoras de cosméticos. 2011.307 p. Tese (doutorado) Universidade Estadual de Campinas, Instituto de Filosofia e Ciências Humanas, Campinas, SP. Disponível em: http://www.repositorio. unicamp.br/handle/REPOSIP/280166. Acesso em: 1 maio 2020.

AMARAL, M. S. Breves considerações acerca das teorias do imperialismo e da dependência ante a financeirização do capitalismo contemporâneo. Revista Pensata, São Paulo, v. 3, n. 1, ano 3, 2013. Disponível em: http://www.unifesp.br/revistas/pensata. Acesso em: 17 fev. 2020.

ANDERSON, P. Balanço do neoliberalismo. In: SADER, E.; GENTILI, P. Pós-neoliberalismo: as políticas sociais e o Estado democrático. Rio de Janeiro: Paz e Terra, 1995.

ANTUNES, R.; ALVES, G. As mutações no mundo do trabalho na era da mundialização do capital. Educ. Soc., Campinas, v. 25, n. 87, maio/ago. 2004.

BORÓN, A. A questão do Imperialismo. In: BORON A. A.; AMADEO, J.; GONZÁLEZ, S. A teoria marxista hoje: problemas e perspectivas. Buenos Aires: Clacso, 2007.

BOTELHO, M. L. Rumo ao desconhecido: endividamento mundial, crise monetária e colapso capitalista. Blog da Boitempo, São Paulo, 23 jun. 2018. Disponível em https://blogdaboitempo.com.br/2018/07/23/rumo-ao-desconhecido-endividamento-mundial-crisemonetaria-e-colapso-capitalista/ Acesso em: 01 maio 2020.

CHESNAIS F. Doze teses sobre a mundialização do capital. In: FERREIRA, C.; FERRI-SCHERER, A. O Brasil frente à ditadura do capital financeiro: reflexões e alternativas. Lajeado: UNIVATES, 2005.

CHESNAIS, F. A mundialização do capital. São Paulo: Xamã, 1996.

CUNHA, J. de S. et al. Crise mundial e a trajetória do Brasil, entre 2008 e 2015. Cadernos do CEAS, Salvador, n. 234, 2005. Disponível em: https://cadernosdoceas.ucsal.br/index.php/cadernosdoceas/article/view/12. Acesso em: 5 maio 2020.

DARDOT, P; LAVAL, C. A nova razão do mundo. Ensaio sobre a sociedade neoliberal. São Paulo: Boitempo, 2016.

DUMÉNIL, G.; LÉVY, D. A crise do neoliberalismo na história do capitalismo. São Paulo: Boitempo, 2013. 
FONTES, V. As contradições da dependência sob o capital-imperialismo. In: SEMINÁRIO INTERNACIONAL SOCIALISMO DEL BUEN VIVIR EM AMÉRICA, Equador, 2013. Disponível em: https://www.planificacion.gob.ec/wp-content/uploads/downloads/2013/05/ Equador-VF-contradicoes-depend-e-kimper-Virgina-Fontes.pdf Acesso em: 23 jan. 2020.

FONTES, V. O Brasil e o capital-imperialismo: teoria e história. Rio de Janeiro: EPSJV; Editora UFRJ, 2010.

GRAMSCI, A. Antologia, Selección, Tradução y Notas de Manuel Sacristan. Madrid: Siglo Veinturno Editores, 1977.

HARVEY, D. O Novo Imperialismo. 8. ed. São Paulo: Edições Loyola, 2014.

HARVEY. D. O neoliberalismo. História e implicações. São Paulo: Edições Loyola, 2008.

IANNI, O. Imperialismo na América Latina. Rio de Janeiro: Ed. Civilização Brasileira, 1974.

LÊNIN, V. I. Imperialismo, estágio superior do capitalismo: ensaio popular. São Paulo: Expressão Popular, 2012.

MARX, K. O capital: crítica da economia política. Livro 1: O processo de produção do capital. [tradução de Rubens Enderle]. São Paulo: Boitempo, 2013.

MARX, K.; ENGELS, F. Manifesto Comunista. São Paulo: Boitempo, 2010.

MÉSZÁROS, I. Para além do Capital: rumo a uma teoria de transição. (trad. Paulo Cesar Castanheira e Sergio Lessa), São Paulo: Boitempo, 2011.

TOUSSAINT, E. As próximas crises financeiras prováveis. Parte 3 da série: A pandemia do capitalismo, o coronavírus e a crise econômica. Comitê para abolição das dívidas ilegítimas, Bélgica, 21 abr. 2020. Disponível em: https://www.cadtm.org/As-proximascrises-financeiras-provaveis. Acesso em: 08 mai. 2020.

TROTSKY, L. Peculiaridades do desenvolvimento da Rússia. In: TROTSKY, L. A História da Revolução Russa: a queda do tzarismo. Tradução E. Huggins. Rio de Janeiro: Paz e Terra, 1977.

\section{Notas}

1 Meio século antes, Marx (2013) já sinalizava que a concentração e centralização do capital o conduziriam ao monopólio e capturava diversos outros elementos que se constituiriam em determinações do imperialismo, tais como a dívida pública, a emergência de uma moderna bancocracia, com suas maltas de "bancocratas, financistas, rentistas, corretores, stockjobbers [bolsistas] e leões da bolsa" e seu sistema internacional de crédito (MARX, 2013, p. 225). Sobre a Holanda - um dos principais países que se tornaria imperialista no início do século XX — MarX afirma que "[...] o país deixara de ser a nação comercial e industrial dominante", para ter como um de seus principais negócios "[...] o empréstimo de enormes somas de capital, especialmente à sua poderosa concorrente, a Inglaterra" (MARX, 2013, p. 225-6). Em 1848, no Manifesto Comunista, Marx e Engels enfatizaram que, devido à necessidade crescente de novos mercados, a burguesia seria sempre impelida a invadir todo o globo terrestre, para criar vínculos e explorar em toda parte (MARX; ENGELS, 2010).

2 Os bancos passaram a dispor de quase todo capital-dinheiro do conjunto dos capitalistas, bem como de meios de produção e de matérias-primas, em diversos países; formaram seus próprios monopólios e participavam de monopólios empresariais, absorvendo e subordinando os menores. A título de ilustração, no início do primeiro decênio do século XX o Banco Alemão congregava, total ou parcialmente, 87 bancos e cerca de 3 bilhões de marcos e, ao final do mesmo decênio, nove bancos berlinenses já concentravam $83 \%$ de todo o capital alemão. Através da exportação de capitais, os bancos passaram a controlar e gerir capitais e rendimentos dos pequenos e grandes patrões, dos empregados e da aristocracia operária de vários países do mundo e assumiram um caráter universal, operando setores de inteligência sobre empresas e ramos de produção, manipulando capitais especulativos e promovendo uma dinâmica de endividamento das economias nacionais (LÊNIN, 2012).

3 Esta assertiva ratifica a tese do desenvolvimento desigual e combinado, proposta e aprimorada por Lênin (2012) e Trotsky (1977), a qual, em última análise, evidencia a impossibilidade de, sob o jugo das determinações capitalistas, os países periféricos, subdesenvolvidos, alcançarem o mesmo grau de desenvolvimento dos países centrais, tendo em vista os processos de industrialização retardatária dos primeiros.

4 Lênin (2012) indica cinco traços fundamentais do imperialismo; sinteticamente: alta concentração da produção e do capital; fusão dos capitais bancário e industrial; exportação de capitais; formação de associações internacionais monopolistas de capitalistas e o termo da partilha do mundo entre as potências capitalistas mais importantes. Amaral (2013) sintetiza as prerrogativas essenciais da dependência apontadas por Lênin, Bukharin e Hobson, que são o parasitismo econômico e a subordinação das classes trabalhadoras dos países periféricos às necessidades da acumulação do capital nos países imperialistas.

5 Borón (2007), por exemplo, alertou para a insuficiência das teorias clássicas quanto à análise de seus elementos no contexto pós-guerras, como a financeirização da economia mundial, a centralidade dos EUA e a assimilação de novos instrumentos de dominação, a exemplo das instituições internacionais e da ingerência dos Estados Unidos sobre as mesmas, convertendo-as em verdadeiras extensões da Casa Branca. 
6 Em 1995, Mészáros (2011) já havia interpretado que a dinâmica do deslocamento expansionista e a acumulação tranquila do capital haviam sofrido uma interrupção tão séria que o sistema foi conduzido à sua atual crise estrutural, repercutindo em mudanças significativas na sua dinâmica sociometabólica, o que, a nosso ver, corrobora as reflexões de Harvey. Para este, o novo imperialismo estaria recrudescendo as práticas espoliativas do célebre período da chamada acumulação primitiva proposto por Marx; pois, nas palavras do autor, "todas as características da acumulação primitiva que Marx menciona permanecem fortemente presentes na geografia histórica do capitalismo até os nossos dias".

7 Harvey (2014) indica, então, os ataques especulativos das instituições financeiras como a vanguarda da atual acumulação por espoliação, cujas características centrais têm sido: as valorizações fraudulentas de ações; os falsos esquemas de enriquecimento rápido; a destruição estruturada ou a dilapidação de ativos, por meio de fusões e aquisições; a promoção de níveis de encargos da dívida, aprisionando as nações ao esquema da dívida etc. E, para além desses traços definidos a partir da esfera financeira foram criados outros mecanismos de acumulação por espoliação: apropriação intelectual de produtos socialmente desenvolvidos por populações nativas, através dos licenciamentos e patenteamentos; mercadificação da natureza (água, terra, sol, ar etc.); privatização de bens públicos e remercantilização de direitos sociais; regressão de estatutos regulatórios de proteção ao trabalho e ao meio ambiente etc., sempre sob a investida dos Estados nacionais em contrarreformas privatizantes, que transferem para as empresas os ativos públicos produtivos do Estado.

8 Destacam-se, dentre as várias agências que compõem esta institucionalidade, a Organização das Nações Unidas (ONU); o Grupo Banco Mundial (GBM), composto por cinco organizações, das quais destacamos o Banco Internacional para Reconstrução e Desenvolvimento (BIRD); a Organização para a Cooperação e Desenvolvimento Econômico (OCDE); a Organização Mundial do Comércio (OMC), que, em 1995, substituiu o Acordo Geral de Tarifas e Comércio, de 1947; e o Fundo Monetário Internacional (FMI). Fontes (2010) avalia que estas instituições difundem formas de agir e pensar do capital-imperialismo; favorecem associações interburguesas; padronizam um modelo democrático fictício; promovem formação técnica e política de quadros nacionais e internacionais, para uma atuação favorável à sociabilidade capital-imperialista; neutralizam lutas sociais e aprofundam traços de dependência nas economias periféricas.

9 Fontes (2013, p. 7) chama atenção, ainda, que, a partir deste período, “[...] A expansão interna do capital se complementa não apenas com a exportação de capitais ou de mercadorias, mas com a produção industrial 'multinacionalizada' realizada em outros países".

10 Nas palavras de Marx (2013, p. 831), “[...] a propriedade privada constituída por meio do trabalho próprio, fundada, por assim dizer, na fusão do indivíduo trabalhador isolado, independente, com suas condições de trabalho, cede lugar à propriedade privada capitalista, que repousa na exploração de trabalho alheio, mas formalmente livre".

11 Essa propriedade monetária concentrada personifica-se numa Oligarquia Financeira internacional, a qual faz sucumbir as empresas que não alcancem as metas máximas de extração. Para empreender o aumento da extração de mais-valor, realizam-se lesivas práticas econômicas, sociais e ambientais, a nível planetário, donde podemos destacar a taxa de utilização decrescente, o desemprego, a precarização do trabalho etc., que devastam os direitos do trabalho, as condições de vida das populações e a natureza, ameaçando a própria vida humana e o planeta.

12 Essas expropriações suprimem as condições de existência dos trabalhadores, para submetê-los ao mercado de força de trabalho e às relações mercantis, numa espécie de subsunção real e total do trabalho. A subsunção total do trabalho, por sua vez, pode ser sumariamente descrita como a disponibilização de todo o tempo dos trabalhadores em benefício do capital, incluindo o tempo de não trabalho. Todas as atividades dos trabalhadores, incluindo lazer e consumo, passam a ser convertidas em atividades de trabalho para o capital. Para uma compreensão introdutória dos conceitos de subsunção formal, real e total do trabalho ao capital, sugerimos a leitura de Antunes e Alves (2004) e Abílio (2011), e, para seu aprofundamento, Marx (2013).

13 Aprofundando-se na discussão da subjetividade neoliberal, Dardot e Laval (2016) apreendem importantes determinações ideopolíticas desse processo, que forjam um sujeito-empresa, para o qual o princípio básico de todas as esferas de sua vida é a concorrência, similarmente às empresas capitalistas; assim, seus valores e comportamentos são condizíveis com a disponibilidade integral ou subsunção total ao capital, requerida pelo neoliberalismo. A emergência deste novo sujeito foi alicerçada em processos objetivos e subjetivos, dados também no âmbito da reestruturação produtiva, que implicaram na fragilização da identidade, consciência e luta de classes, donde se destacam a desterritorialização da produção e a consequente quebra na pertença ao chão da fábrica; a fragmentação e lógica concorrencial da nova gestão da força de trabalho empregada, aniquilando a solidariedade de classe; e, por fim, a desfiliação sindical (juntamente com uma espécie de repulsa partidária).

14 Neste caso, assim como a divisão social do trabalho sempre expressou a relação de propriedade do capital sobre os meios de produção, as atuais formas precarizadas e subproletarizadas de trabalho expressam a nova forma de propriedade monetária concentrada do capital e suas inflexões sobre o conjunto das empresas de capital produtivo/funcionante, o que coloca os trabalhadores em situação de competição internacional por escassos postos de trabalho estáveis, acirrando a concorrência, o racismo e a xenofobia, em âmbitos nacional e internacional. 
15 Sob a atual e decadente fase do capital, de produção destrutiva e sobreacumulação crônica, as espoliações contemporâneas se configuram, centralmente, como estratégia de impedimento de que qualquer novo modo de produção possa ser erigido a partir do recrudescimento das contradições do capital e seus limites absolutos e dos inexoráveis avanços de suas próprias forças produtivas. Esta atual acumulação predatória, sob a nova dinâmica da propriedade monetária concentrada do capital, opera uma espécie de acumulação primitiva invertida, porque — não sendo originária de absolutamente nada — através de suas espoliações, faz uma reserva de riqueza que visa ao impedimento de que o velho e decrépito mundo capitalista sucumba à potencialidade de que emerja - das suas próprias contradições — um novo modo de produção. Enfim, parafraseando Gramsci (1977), o atual recrudescimento das espoliações é um dos monstros que anunciam a morte lenta deste velho mundo capitalista e a urgência e latência do aparecimento de uma nova ordem social.

16 Afinal, personificada na Oligarquia Financeira internacional e apropriando-se de recentes avanços microeletrônicos, a nova propriedade monetária concentrada do capital adquiriu uma potencialidade inaudita de espoliar/expropriar, extrair mais-valor, comercializar e especular em escala planetária, investindo e desinvestindo, de forma automatizada e instantânea, em qualquer economia nacional, em benefício de sua acumulação.

17 A desterritorialização e externalização da produção, a terceirização, a polivalência, a uberização e o desassalariamento compõem essa reestruturação produtiva, pautada no modelo de acumulação flexível. Para apropriar-se do fenômeno da reestruturação produtiva, dentre a larga referência de autores que discutem o tema, recomendamos a pesquisa das obras de Ricardo Antunes, Luciano Vasapollo, Ruy Braga e Pietro Basso.

18 Com diferentes variantes, as proposituras do neoliberalismo foram gestadas desde a década de 1920 — passando pelo Colóquio de Lipmann, em 1938; pelas elaborações de Hayek, na obra O caminho da servidão (1944) e pela criação da Sociedade de Mont Pelerim, em 1947 (DARDOT; LAVAL, 2016); no entanto, apenas em meados da década de 1980 - com os seus projetos pilotos nos governos Pinochet/Chile (1973-1990); Thatcher/Inglaterra (1979-1990) e Reagan/EUA (1981-1989) — é que as proposituras hayekianas (com colaborações de Mises, Friedman e outros) foram empreendidas, para fazer frente à crise estrutural do capital e objetivar as potencialidades da nova propriedade monetária concentrada do capital, através, principalmente, do já referido tripé de liberalização, desregulamentação e privatização, imposto às economias nacionais.

19 Dentre essas pautas, podemos destacar as recomendações de controle da moeda e da inflação; disciplina fiscal; redução de gastos públicos; câmbio flutuante; desregulamentação e abertura financeira e comercial e flexibilização de leis e direitos trabalhistas. Para uma aproximação com a discussão do neoliberalismo, suas pautas macroeconômicas e suas implicações, sugerimos, inicialmente, a leitura de Anderson (1995) e Harvey (2008).

20 Embora esta obra se paute, significativamente, nas elaborações de Foucault e não se debruce sobre alguns determinantes de ordem econômica, identificamos ao menos duas contribuições importantes das suas minuciosas análises: a apreensão das composições e desdobramentos do neoliberalismo no componente de subjetividade que integra a universalidade e totalidade da relação social capitalista (não devendo ser negligenciada esta dimensão subjetiva) e uma criteriosa apresentação historiográfica da elaboração teórico-política e ideológica do pensamento neoliberal, desde sua origem até os dias atuais; permitindo-nos apreender seus elementos de continuidade e ruptura em relação ao liberalismo clássico.

21 Necessário ressaltar que os sinais da crise financeira de 2008 já se faziam sentir em 2007, quando, em fevereiro, o HSBC revela perdas no mercado de hipotecas norte-americanas e, em agosto, o PNB Paribas revela impactos da crise americana de subprime sobre três de seus fundos de investimento de alto risco (hedge), na França (CUNHA et al., 2015).

22 Embora o crescimento das dívidas, especialmente públicas, sejam consequência das fragilidades e instabilidades da própria hegemonia do capital financeiro, elas são instrumentalizadas como mecanismos de apropriação dos fundos públicos das nações, transferindo para as economias centrais o mais-valor produzido na periferia e atuando numa perspectiva de (RE)subordinação permanente das economias dependentes às economias imperialistas. Também os Investimentos Estrangeiros Diretos (IEDs), especialmente os IEDs do setor financeiro, foram largamente ampliados através da liberalização e desregulamentação empreendidas pelo neoliberalismo. Segundo Duménil e Lévy (2011), entre a década de 1970 e o ano de 2008, o volume de empréstimos de todos os bancos mundiais para tomadores estrangeiros cresceu 52 vezes; enquanto que o fluxo global de IEDs cresceu 48 vezes, também entre os anos de 1970 e os anos 2000.

23 A título de ilustração da financeirização das economias nacionais, em 2007, os ativos estrangeiros na economia dos EUA eram o dobro dos ativos dos EUA no estrangeiro. A riqueza do país era, pois, exportada para os países de origem dos especuladores e credores, na forma de juros, gerando endividamento (familiar e público) e déficit comercial (DUMÉNIL; LÉVY, 2011). O setor imobiliário era o âmbito de maior especulação e de fato foi o detonador da crise.

24 Notadamente, os Acordos de Basileia III, para o pós-crash, cujas proposições eram de uma supervisão centralizada de todos os bancos da zona do euro; de criação de um fundo europeu de garantia de depósitos; a proibição de algumas operações de risco e a limitação dos bônus e maior transparência nas transações, dentre outras (TOUSSAINT, 2020).

25 Dentre outros aspectos, a economia chinesa é marcada por maior controle das taxas de câmbio e da movimentação de capitais; predominância de bancos estatais; regulação de bolsas de valores e mercados financeiros; agressiva política industrial sob a 
propriedade do Estado (BOTELHO, 2018). As relações deste país com economias periféricas (notadamente na América Latina e na África) imprimiram alterações significativas nas disputas imperialistas nas regiões e continentes do planeta e colocou-o na linha de frente da disputa por hegemonia com os Estados Unidos. Julgamos oportuno lembrar que as relações imperialistas se dão na perspectiva da competição, disputa e subordinação entre as economias nacionais centrais e periféricas, para forjar e recompor, permanentemente, o desenvolvimento desigual e combinado necessário à acumulação do capital, tanto na universalidade quanto na particularidade interna dessas mesmas economias, onde se acirram, de forma mais direta, palpável e apreensível, a luta de classes e as desigualdades entre elas, sendo o imperialismo um momento imanente ao capital e sua ofensiva sobre o trabalho.

26 Tristemente ilustrativo deste fato é o atual genocídio indígena, no Brasil, para apropriação e transferência de suas terras, especialmente, para a atividade mineradora, dentre outras.

27 Exemplo contundente deste otimismo foi a avaliação de E. Hobsbawn, de que, frente à crise, haveria uma retomada de princípios keynesianos na economia e no papel do Estado, em detrimento da lógica liberalizante e desregulamentadora do neoliberalismo (HOBSBAWN apud CUNHA et al., 2015).

28 Corroborando nossas apreensões, até mesmo grandes representantes de interesses do capital vêm criticando a manutenção dessa desregulamentação e requerendo a domesticação das finanças; a repressão financeira ou a limitação do fluxo de capitais e, ainda, a taxação de altos salários e rendimentos, como afirmam Duménil e Lévy (2011), referindo-se, respectivamente a Joseph Stiglitz; ao Boston Consulting Group e a Warren Buffet.

29 Entre os meses de fevereiro e março de 2020, frente ao agravamento da crise com a pandemia do coronavírus, as bolsas de todos os continentes registraram perdas entre 20 e 40 pontos percentuais; apenas a China conseguiu limitar as perdas nas suas bolsas, que ficaram em torno de $7 \%$ (TOUSSAINT, 2020).

\section{Sheyla Suely de Souza Silva}

sheylasuelyss@hotmail.com

Doutora em Serviço Social pela Universidade Federal de Pernambuco (UFPE)

Professora Adjunta do Departamento de Serviço Social e do Programa de Pós-graduação em Serviço Social da Universidade Estadual da Paraíba (UEPB)

\section{UEPB}

Rua Baraúnas, 351 - Bairro Universitário

Campina Grande-PB - Brasil

CEP: 58429-500

\section{Agradecimentos}

Ao Grupo de História do Trabalho Global e dos Conflitos Sociais, do Instituto de História Contemporânea/Universidade Nova de Lisboa, pelo acolhimento e apoio ao nosso plano de estudos de pós-doutoramento, do qual resulta esta primeira síntese teórica.

\section{Agência financiadora}

Não se aplica.
Contribuições da autora

Não se aplica.

Aprovação por Comitê de Ética e consentimento para participação

Não se aplica.

Consentimento para publicação

Consentimento da autora.

Conflito de interesses

Não há conflito de interesses. 